\title{
STRATEGI PEMASARAN KELOMPOK BIMBINGAN IBADAH HAJI DAN UMROH AL MABRUR LUMAJANG
}

\author{
Fathur Rohman \\ Prodi Manajemen Dakwah \\ Fakultas Dakwah dan Komunikasi Islam \\ Institut Agama Islam Syarifuddin Lumajang \\ Email : ahmadfathur99@gmail.com
}

\begin{abstract}
This study examines the marketing strategies of Hajj Guidance Groups (KBIH/ KelompokBimbinganlbadah HajidanUmroh) Al MabrurLumajang. The method used is qualitative descriptive. The applied Data collection techniques areinterviews, observation and documentation. Data analysis uses descriptive qualitative. The conclusion of this study is the marketing strategy is carried out in four stages: promotion, product provision, affordable prices, and strategic office locations. The marketing supporting factors are the loyalty of consumers, the provision of good services, affordable prices, the existence of alumni ties among Hajj pilgrims, and the number of Al Mabrur KBIH officers who are adequate for Lumajang scope. The factors that hinder marketing are the growth of more competitors, the lack of human resourcesquality, and the absence of KBIH blog and website.
\end{abstract}

Key Words: Marketing Strategies, Hajj Guidance Groups, the Marketing Supporting Factors

\section{PENDAHULUAN}

Semua orang islam mengiginkan untuk melaksanakan ibadah haji, untuk melaksanakan haji memerlukan biaya yang tidak sedikit dan kekuatan fisik serta mental yang kuat. Haji adalah sambutan panggilan Allah SWT maka sudah wajar melakukan haji penuh dengan kerinduan dan cinta, jamaah haji adalah tamu-tamu Allah. Jika berdoa pasti dikabulkan, jika minta ampun pasti diampuni. Allah berfirman, yang artinya:

"Padanya terdapat tanda-tanda yang nyata, (di antaranya) maqam Ibrahim; barangsiapa memasukinya (Baitullah itu) menjadi amanlah Dia. Mengerjakan haji adalah kewajiban manusia terhadap Allah, yaitu (bagi) orang yang sanggup mengadakan perjalanan ke Baitullah. Barangsiapa mengingkari (kewajiban haji) maka 
sesungguhnya Allah Maha Kaya (Tidak memerlukan sesuatu) dari semesta alam." (QS. Ali Imran: 97)

Pada dasarnya para calon jamaah haji berniat untuk beribadah, serta berusaha untuk melaksanakan ibadah haji sebaik mungkin. Sehingga perlu dilakukan pembimbingan seintensif mungkin, karena semua jamaah haji tidak pasti mengetahui tata cara melakukan ibadah haji, khususnya untuk jamaah yang sudah berusia lanjut.

Tahun 2006 Puslitbang Kehidupan Keagamaan mengadakan penelitian “Persepsi Calon Jamaah Haji terhadap Kualitas Pembimbingan KBIH dan non KBIH di Indonesia-Arab Saudi”.Terdapat perbedaan persepsi/penilaian antara jamaah haji KBIH dan non KBIH terhadap kualitas kepembimbingan yang dilakukan. Secara umum $\mathrm{KBIH}$ lebih siap dan lebih baik dalam hal pembimbingan dibandingkan non KBIH. ${ }^{2}$

Bimbingan Kelompok Ibadah Haji ( KBIH ) adalah lembaga Sosial Keagamaan yang telah mendapat izin Kementerian Agama untuk melaksanakan bimbingan terhadap jemaah haji. ${ }^{3}$ Lembaga ini memiliki peran untuk membantu calon jamaah haji yang hendak menunaikan ibadah haji ke tanah suci Makkah. Jumlah KBIH semakin banyak dan seiring dengan itu orientasi bisnisnya juga semakin menonjol. Berkenaan dengan itu, maka pemerintah melakukan berbagai pengaturan agar kegiatankegiatan KBIH tersebut tidak merugikan masyarakat yang akan melaksanakan ibadah haji. Pemerintah menjadikan pihak swasta khususnya KBIH tersebut sebagai mitra dengan memberikan wewenang dalam bidang bimbingan ibadah, bukan dalam bidang operasional teknis penyelenggaraan ibadah haji.

$\mathrm{KBIH}$ yang ingin memiliki calon jamaah haji sepanjang hidupnya, perlu memberikan kepuasan kepada setiap jamaahnya bahkan menciptakan loyalitas agar mereka menjadi pelanggan yang setia. Disamping itu juga, dalam KBIH diperlukan pemasaran untuk mendapatkan calon jamaah haji agar masyarakat atau jamaahnya lebih banyak. Pemasaran sebagai suatu proses sosial dan manajerial yang membuat individu dan kelompok memperoleh apa yang mereka butuhkan dan inginkan, lewat

\footnotetext{
${ }^{1}$ QS. Ali Imran: 97

${ }^{2}$ Imam Syaukani, Manajemen Pelayanan Haji Di Indonesia (Departemen Agama RIBadan Litbang dan DiklatPuslitbang Kehidupan Keagamaan, 2009). 6

3http://jatim.kemenag.go.id/file/file/haji/isaq1426576477.pdf. diakses 1 februari 2018

Volume 4, Nomor 2, Agustus 2018| 198
} 
penciptaan dan pertukaran timbal balik produk dan nilai dengan orang lain. ${ }^{4}$ menurut W.J. Stanton yang dikutip M. Mursid dalam buku manajemen pemasaran mengatakan pemasaran meliputi kesuluruhan sistem yang berhubungan dengan kengiatankengiatan usaha, yang bertujuan merencanakan, menentukan harga, hingga mempromosikan, dan mendistribusikan barang-barang, baik yang aktual maupun potensial. ${ }^{5}$

Strategi pemasaran merupakan hal yang sangat penting bagi perusahaan dimana strategi pemasaran merupakan suatu cara mencapai tujuan dari sebuah perusahaan. Strategi pemasaran merupakan rencana yang menjabarkan espektasi perusahaan akan dampak dari berbagai aktivitas atau perogram pemasaran terhadap permintaan produk atau lini produk di pasar sasaran. ${ }^{6}$

Dalam strategi pemasaran perusahan terlebih dahulu melakukan strategi segmentasi, penetapan pasar sasaran, penetapan posisi perusahaan. Dan dalam strategi pemasaran terdapat bauran pemasaran, Menurut Kotler yang dikutip oleh Novianti bauran pemasaran (marketing mix) adalah seperangkat alat pemasaran yang digunakan perusahaan untuk terus menerus mencapai tujuan pemasarannya. Dalam bauran pemasaran terdapat seperangkat alat pemasaran yang dikenal dalam istilah 4P, yaitu product (produk), price (harga), place (tempat), atau (saluran distribusi), dan promotion (promosi). ${ }^{7}$

Tidak dapat dipungkiri bahwa promosi adalah salah satu faktor yang diperlukan bagi keberhasilan dalam strategi pemasaran yang diterapkan suatu lembaga terutama pada saat ini ketika era reformasi berkembang pesat, maka promosi merupakan salah satu senjata ampuh bagi lembaga dalam mengembangkan dan mempertahankan usaha. Promosi adalah komunikasi yang persuasif, mengajak, mendesak, membujuk, meyakinkan. ${ }^{8}$ Secara garis besar tujuan promosi dapat dibagi menjadi dua, yaiu Tujuan jangka panjang (misalnya: membangung nama baik

\footnotetext{
${ }^{4}$ Kotler dan Amrstrong, Perinsip-Perinsip Pemasaran, (Jakarta: Erlangga, 2001). 7

${ }^{5}$ M. Mursid, Manajemen Pemasaran, (Jakarta: PT Bumi Aksara. 2003). 26

${ }^{6}$ Gregorius Chandra, Strategi dan Program Pemasaran, (Yogyakarta: Andi. 2002). 93

${ }^{7}$ Devi Noviyanti, "Pentingnya Implementasi Strategi Pemasaran Bagi Travel Haji dan Umroh di Banjarmasin" jurnal ilmu dakwah juli-desember 2015. 20

${ }^{8}$ Mursid, Manajemen Pemasaran, 95
} 
perusahaan, mendidik konsumen, dan menciptakan reputasi tinggi dari suatu produk), ${ }^{9}$ tujuan jangka pendek (misalnya menaikkan penjualan, mengumumkan lokasi agen dan mengumumkan perubahan/penyempurnaan produk).

Di Kabupaten Lumajang terdapat beberapa KBIH yang menyediakan manasik haji antara lain KBIH Makkah Wal Madinah, KBIH Miftahul Ulum, KBIH Al-Mabrur, KBIH Arofah, KBIH Al Haromain. KBIH yang Banyak di Kabupaten Lumajang membuat terjadinya persaingan dan setiap kelompok bimbingan ibadah haji (KBIH) berusaha memperoleh tujuan serta dapat bertahan selamanya.

Begitu banyak KBIH yang melayani masyarakat untuk melaksanakan ibadah haji, dan semakin bertambah masyarakat yang berminat untuk melakasakan ibadah haji disertai dengan banyaknya permintaan sehingga semakin besar tantangan untuk menigkatkan kualitas KBIH dalam segala hal. Karena permasalahan yang dihadapi oleh Kelompok Bimngan Ibadah Haji (KBIH) Al Mabrur Lumajang semakin beragam, maka sudah selayaknya segala sesuatu yang berhubungan dengan manajemen harus semakin ditinggatkan agar strategi yang dilakukan dalam target pasar calon jamaah haji tercapai dengan baik dan program-program yang dijalankan berjalankan lancar sesuai dengan tujuan yang diingikan.

Saat ini ada enam yang melayani bimbingan manasik haji diantaranya KBIH Makkah Wal Madinah, KBIH Miftahul Ulum, KBIH Al-Mabrur, KBIH Arofah, KBIH Al Haromain, KBIH Bustanul Ulum. KBIH Al-Mabrur sendiri berada di urutan nomor dua setelah KBIH Makkah Wal Madinah dilihat dari segi banyaknya jamaah haji setiap tahun. KBIH Al-Mabrur memiliki keunggulan dari segi pelayanan serta kejujuran dalam pelaporan biaya yang dikeluarkan oleh jamaah. Dari sinilah KBIH Al-Mabrur Lumajang mendapat kepercayaan yang lebih dari jamaah, sehingga para calon jamaah haji tertarik untuk memilih KBIH Al-Mabrur Lumajang sebagai pembimbing dalam perjalanan hajinya.

$\mathrm{KBIH}$ Al-Mabrur yang berada di tengah-tengah kota yang membuat tempat strategis. Dan KBIH Al-Mabrur dalam melaksanakan manasik haji bertempat di jalan lintas selatan (JLT) disana ada aula gedungnya. Dalam melakukan stategi pemasaran

\footnotetext{
${ }^{9}$ Mursid, Manajemen Pemasaran, 95
} 
KBIH Al-Mabrur mempunyai tiga cara, pertama dengan mempromosikan yang ada di KBIH Al-Mabrur baik segi fasilitas, harga, pelayanan dan yang lain. KBIH Al-Mabrur mempromosikan lewat brosur, media, kalender. Kedua dalam mempromosikan kepada jamaah KBIH Al-Mabrur tidak menjelekkan KBIH yang lain. ketiga dengan startegi setiap jamaah yang sudah berangkat haji dijadikan saudara agar ketika ada kerabatnya atau tetangganya ketika didaftarkan haji mengikuti bimbingan manasik haji KBIH Al-Mabrur.

Berdasarkan latar belakang di atas peneliti tertarik meneliti denganpermasalahansebagaiberikut, pertama, agaimana strategi pemasaran kelompok bimbingan ibadah haji (KBIH) dan umroh Al Mabrur Lumajang dalam manasik haji dan umroh?Kedua, apa saja faktor pendukung strategi pemasaran kelompok bimbingan ibadah haji (KBIH) dan umroh Al Mabrur Lumajang dalam manasik haji dan umroh?Ketiga, apa saja faktor penghambat strategi pemasaran kelompok bimbingan ibadah haji (KBIH) dan umroh Al Mabrur Lumajang dalam manasik haji dan umroh?

\section{METODE PENELITIAN}

\section{Pendekatan dan Jenis Penelitian}

Adapun pendekatan penelitian yang dipakai adalah pendekatan kualitatif, metode tersebut dapat diartikan sebagai penelitian yang bermaksud untuk memahami fenomena tentang apa yang dialami oleh subyek penelitian. ${ }^{10}$

Penelitian tentang strategi pemasaran kelompok bimbingan ibadah haji (KBIH) dan umroh Al Mabrur Lumajang dalam manasik haji dan umroh, nantinya peneliti akan mencari data-data deskriptif kualitatif yaitu lebih menyajikan rincian menyajikan dari ringkasan, karena Jenis penelitian ini termasuk dalam penelitian deskriptif, yaitu penelitian yang menggambarkan, meringkas berbagai kondisi, situasi atau berbagai variabel. ${ }^{11}$

Sesuai dengan fokus dan tujuan penelitian ini, jenis penelitian ini sangat tepat karena peneliti akan mendeskripsikan data. Dalam penelitian ini peneliti akan

\footnotetext{
${ }^{10}$ Lexy J. Moleong, Metodologi Penelitian Kualitatif, (Bandung: Remaja Rosydakarya, 2002), 6 ${ }^{11}$ Lexy J. Moleong, Metodologi Penelitian Kualitatif, 14 
mendeskripsikan hal-hal yang terjadi di KBIH Al Mabrur Lumajang tentang strategi pemasaran dalam manasik haji dan umroh.

\section{Lokasi Penelitian}

Adapun lokasi penelitian ini di kelompok bimbingan ibadah haji (KBIH) AlMabrur JL. Juanda No 10 Kelurahan Rogotrunan Lumajang. Peneliti mengambil penelitian di KBIH Al Mabrur karena mempunyai strategi pemasaran yang cukup efektif dengan cara, pertama dengan mempromosikan yang ada di KBIH Al-Mabrur baik segi fasilitas, harga, pelayanan dan yang lain. KBIH Al-Mabrur mempromosikan lewat brosur, media, kalender. Kedua dalam mempromosikan kepada jamaah KBIH Al-Mabrur tidak menjelekkan KBIH yang lain. ketiga dengan startegi setiap jamaah yang sudah berangkat haji dijadikan saudara agar ketika ada kerabatnya atau tetangganya ketika didaftarkan haji mengikuti bimbingan manasik haji KBIH AlMabrur.

KBIH Al Mabrur Lumajang melaksanakan bimbingan manasik haji lebih awal. Pada tahun 2018 sudah malaksanakan 15 kali bimbingan manasik haji sampai bulan februari untuk mempersiapkan para jamaah lebih paham tata cara haji dan ketika sudah sampai di makkah tidak terlalu kebingungan melaksanakan ibadah haji.

\section{Sumber Data}

1 Person yaitu sumber data yang bisa memberikan data berupa jawaban lisan melalui wawancara atau jawaban tertulis melalui angket. ${ }^{12}$ Adapun orang yang menjadi sumber data sebagai berikut:

a. Ketua kelompok bimbingan ibadah haji (KBIH) AIMabrur Lumajang

b. Bagian pemasaran kelompok bimbingan ibadah haji (KBIH) AlMabrur Lumajang

c. Orang yang pernah menjadi jamaah haji pada tahun 2017 di kelompok bimbingan ibadah haji (KBIH) AlMabrur Lumajang

2 Place yaitu sumber data yang menyajikan tampilan berupan keadaan diam dan bergerak. ${ }^{13}$

\footnotetext{
${ }^{12}$ Suharmisi Arikunto, Prosedur Penelitian Suatu Pendekan Peraktik, (Jakarta: Pt Rineka Cipta, 2006), 129

${ }^{13}$ Arikunto, Prosedur Penelitian Suatu Pendekan Peraktik. 129 
Adapun tempat yang menjadi sumber data sebagai berikut:

a. Tempat kelompok bimbingan ibadah haji (KBIH) Al Mabrur Lumajang

b. Suluruh aktivitas yang berhubungan dengan strategi pemasaran di kelompok bimbingan ibadah haji (KBIH) Al Mabrur Lumajang

3 Paper yaitu sumber data yang menyajikan tanda-tanda berupa huruf, angka, gambar, atau simbol-simbol lain. ${ }^{14}$

Adapun paper yang menjadi sumber data sebagai berikut:

a. Dokomen-dokumen kelompok bimbingan ibadah haji (KBIH) Al Mabrur Lumajang

b. Gambar tentang aktivitas kelompok bimbingan ibadah haji (KBIH) Al Mabrur Lumajang

\section{Teknik Pengumpulan Data}

Adapun teknik pengumpulan data menggunakan tiga cara, yaitu:

a. Observasi

Observasi yaitu melengkapi dengan format atau belangko pengamatan sebagai instrumen. Format yang disusun berisi item-item kejadian atau tingkah laku yang digambarkan akan terjadi ${ }^{15}$

Teknik observasi ini digunakan untuk mengadakan pengamatan secara langsung yang bersifat fisik mengenai tentang strategi pemasaran kelompok bimbingan ibadah haji (KBIH) dan umroh Al Mabrur Lumajang dalam manasik haji dan umroh.

b. Wawancara

Wawancara adalah merupakan petemuan dua orang untuk bertukar informasi dan ide, melalui tanya jawab, sehingga dapat dikonstruksikan makna dalam suatu topik tertentu. ${ }^{16}$

${ }^{14}$ Arikunto, Prosedur Penelitian Suatu Pendekan Peraktik. 129

${ }^{15}$ Arikunto, Prosedur Penelitian Suatu Pendekan Peraktik, 229

${ }^{16}$ Sugiyono. 2010. Metode Penelitian Kuatitatif Kualitatif dan R\&D, (Bandung: alfabeta. 2010). 231. 
Teknik wawancara digunakan untuk memperoleh data tentang tentang strategi pemasaran kelompok bimbingan ibadah haji (KBIH) dan umroh Al Mabrur Lumajang dalam manasik haji dan umroh.

Wawancara ini dilakukan kepada kepala kelompok bimbingan ibadah haji (KBIH) Al Mabrur Lumajang, bagian lapangan, staff yang lain dan jama'ah atau alumni jamaah haji.

Adapun wawancara yang dilakukan meliputi tentang,

1) strategi pemasaran kelompok bimbingan ibadah haji $(\mathrm{KBIH})$ dan umroh $\mathrm{Al}$ Mabrur Lumajang dalam manasik haji dan umroh.

2) Faktor pendukung strategi pemasaran kelompok bimbingan ibadah haji (KBIH) dan umroh Al Mabrur Lumajang dalam manasik haji dan umroh.

3) Faktor penghambat strategi pemasaran kelompok bimbingan ibadah haji (KBIH) dan umroh Al Mabrur Lumajang dalam manasik haji dan umroh.

c. Dokumentasi

Dokumentasi merupakan catatan peristiwa yang sudah berlalu. Dokumen bisa berbentuk tulisan, gambar, atau karya-karya monumental dari seseorang. ${ }^{17}$

Teknik dokumentasi digunakan untuk mengetahui data mengenai letak kantor, sejarah berdirinya kelompok bimbingan ibadah haji (KBIH) Al Mabrur Lumajang. struktur organisasi, jumlah karyawan, serta hal-hal lain yang berkaitan dengan penelitian.

\section{AnalisisData}

Metode analisis data yang digunakan dalam penelitian ini menggunakan metode analisis model miles dan huberman. Yang mana menurur miles dan huberman yang dikutip oleh sugiyono mengemukakan bahwa aktivitas dalam analisis data kualitatif dilakukan secara interaktif dan berlangsung secara terus menerus sampai tuntas, sehingga datanya sudah jenuh. Aktivitas dalam

${ }^{17}$ Sugiyono ,Metode Penelitian Kuatitatif Kualitatif dan R\&D,240

Volume 4, Nomor 2, Agustus 2018| 204 
analisis data, yaitu data reduction, data display, dan data conclusion drawing/verification. ${ }^{18}$

a. Data Reduktion (Riduksi Data)

Mereduksi data yaitu merangkum, memilih hal-hal yang pokok, memfokuskan pada hal-hal yang penting, dicari tema dan polanya. Dalam hal ini, ketika peneliti memperoleh data dari lapangan dengan jumlah yang cukup banyak. Maka perlu segera dilakukan analisis data melalui reduksi data. Adapun hasil dari mereduksi data, peneliti telah memfokuskan pada strategi pemasaran kelompok bimbingan ibadah haji (KBIH) dan umroh Al Mabrur Lumajang dalam manasik haji dan umroh dan faktor pendukung dan penghambat startegi pemasaran kelompok bimbingan ibadah haji (KBIH) dan umroh Al Mabrur Lumajang dalam manasik haji dan umroh.

b. Data display (penyajian data)

Setelah data di reduksi, selanjutnya peneliti menyajikan data yang berarti mengorganisir data, menyusun data dalam suatu pola hubungan sehingga semakin mudah di pahami. Dalam hal ini, peneliti memfokuskan bagaimana strategi pemasarankelompok bimbingan ibadah haji $(\mathrm{KBIH})$ dan umroh Al Mabrur Lumajang dalam manasik haji dan umroh dan faktor pendukung dan penghambat startegi pemasaran kelompok bimbingan ibadah haji (KBIH) dan umroh Al Mabrur Lumajang dalam manasik haji dan umroh.

c. data conclusion drawing/verification

Langkah ke tiga dalam analisis data kualitatif menurut Miles dan Huberman adalah penarikan kesimpulan. Diharapkan, penarikan kesimpulan yang dilakukan oleh peneliti mampu menjawab rumusan masalah yang telah dirumuskan yakni strategi pemasaran kelompok bimbingan ibadah haji (KBIH) dan umroh Al Mabrur Lumajang dalam manasik haji dan umroh, faktor pendukung dan penghambat startegi pemasaran kelompok bimbingan ibadah haji (KBIH) dan umroh Al Mabrur Lumajang dalam manasik haji dan umroh.

${ }^{18}$ Sugiyono,Metode Penelitian Kuatitatif Kualitatif dan R\&D, 246 


\section{Keabsahan Data}

Untuk menguji keabsahan data dalam penelitian kualitatif yakni menggunakan triangulasi dan teknik perpanjangan pengamatan. Triangulasi dalam pengujian kredibilitas ini diartikan sebagai pengecekan data dari berbagai sumber dengan berbagai cara, dan berbagai waktu. Dengan demikian terdapat trianngulasi sumber, triangulasi teknik pengumpulan data, dan waktu. ${ }^{19}$

a. Peneliti malakukan pengecekan dengan menggunakan triangulasi sumber adalah untuk menguji kredibilitas data dilakukan dengan cara mengecek data yang telah diperoleh melalui beberapa sumber. Dari ke tiga sumber tersebut, tidak bisa dirata-ratakan seperti dalam penelitian kuantitatif, tetapi dideskripsikan, dikategorisasikan, mana pandangan yang sama, yang berbeda, dan mana spesifik dari tiga sumber data tersebut. ${ }^{20}$

b. Peneliti menggunakan triangulasi teknik untuk menguji kredibilitas data dialakukan dengan cara mengecek data kepada sumber yang sama dengan teknik yang berbeda. Bila dengan tiga teknik pengujian kredibilitas data tersebut, mengahasilkan data yang berbeda-beda, maka peneliti melakukan diskusi labih lanjut kepada sumber data yang bersangkutan atau yang lain, untuk memastikan data mana yang dianggap benar. ${ }^{21}$

c. Waktu juga sering mempengaruhi krediblitas data. Data yang dikumpulkan dengan teknik wawancara di pagi hari pada saat narasumber masih segar. Untuk itu dalam rangka pengujian kredibilitas data dapat dilakukan dengan cara melakukan pengecekan dengan wawancara, observasi atau teknik lain dalam waktu atau situasi yang berbeda.

d. Dalam pengujian keabsahan data peneliti juga menggunakan teknik meningkatkan ketekunan. Meningkatkan ketekunan berarti melakukan pengamatan secara lebih cermat dan berkesinambungan. Dengan cara tersebut maka kepastian data dan urutan peristiwa akan dapat direkam secara pasti dan sistematis.

\footnotetext{
${ }^{19}$ Sugiyono,Metode Penelitian Kuatitatif Kualitatif dan R\&D, 273

${ }^{20}$ Sugiyono,Metode Penelitian Kuatitatif Kualitatif dan R\&D, 274

${ }^{21}$ Sugiyono,Metode Penelitian Kuatitatif Kualitatif dan R\&D, 274
} 


\section{PEMBAHASAN}

\section{Strategi}

a. Pengertian Strategi

Pengertian strategi menurut Sun Tzu, Hannthal, dan Carl Von Clausewitz yang dikutip oleh Effendi $M$ Guntur mendefinisikan strategi menggambarkan arah bisnis yang mengikuti lingkungan yang dipilih dan merupakan pedoman untuk mengalokasikan sumber daya dan usaha suatu organisasi. $^{22}$

Menurut Effendi M Guntur mendefiniskan strategi sebagai program untu menentukan dan mencapai tujuan organisasi dan mengimplemtasikan misisnya. ${ }^{23}$

b. KonsepStrategi

Menurut Hayes dan Wheelwright yang dikutip oleh Effendi M, Guntur menyatakan bahwa dalam suatu perusahaan terdapat tiga level strategi, yaitu level korporasi, level unit bisnis atau lini bisnis, dan level fungsional. ${ }^{24}$

1) Strategi Level Korporasi

Strategi level korporasi dirumuskan oleh manajemen puncak yang mengatur kegiatan dan operasi organisasi yang memiliki lini atau unit bisnis lebih dari satu.

2) Strategi Level Unit Bisnis Atau Lini Bisnis

Strategi level unit bisnis atau lini bisnis lebih diarahkan pada pengelolaan kegiatan dan operasi suatu bisnis tertentu. Pada dasarnya Strategi level unit bisnis atau lini bisnis berupaya menentukan pendekatan yang sebaiknya digunakan oleh suatu bisnis terhadap pasarnya dan bagaimana melaksanakan pendekatan tersebut dengan memanfaatkan sumber daya yang ada dan dalam kondisi pasar tertentu.

\footnotetext{
${ }^{22}$ Effendi M Guntur, transformasi manajemen pemasaran.(Jakarta: CV Sagung Seto.2010) 33.

${ }^{23}$ Guntur, Transformasi Manajemen Pemasaran, 34.

${ }^{24}$ Guntur, Transformasi Manajemen Pemasaran, 34. 
3) Strategi Level Fungsional

Strategi Level Fungsional merupakan strategi dalam kerangka fungsi-fungsi manajemen ( secara tradisional terdiri atas riset dan pengembangan, keuangan, produksi dan operasi, pemasaran, personalia/sumber daya manusia ) yang dapat mendukung strategi level unit bisnis.

Strategi fungsional umumnya lebih terperinci dan memiliki jangka waktu yang lebih pendek daripada strategi organisasi. Tujuan pengembangan strategi fungsional adalah untuk mengkomunikasikan tujuan jangka pendek, menentukan tindakan-tindakan yang dibutuhkan untuk mencapai tujuan jangka pendek, dan untuk menciptakan lingkungan yang kondusif bagi pencapaian tujuan tersebut. Strategi fungsional perlu dikoordinasikan satu sama lain untuk menghindari terjadinya konflik kepentingan dalam organisasi.

\section{Pemasaran}

a. Pengertian pemasaran

Beberapa ahli memberikan bermacam-macam definisi tentang pemasaran antara lain: ${ }^{25}$

1) Philip dan duncan mendefinisikan pemasaran meliputi semua langkah yang digunakan atau dipergunakan untuk menempatkan barang-barang nyata ke tangan konsumen

2) W.J. Stanton mendefinisikan pemasaran meliputi keseluruhan sistem yang berhubungan dengan kegiatan-kegiatan usaha, yang bertujuan merencanakan, menentukan harga, hingga mempromosikan, dan mendistribusikan barang-barang jasa yang akan memuaskan kebutuhan pembeli, baik yang aktual maupun yang potensial.

3) P.H. Nystrom mendefinisikan pemasan meliputi segala kengiatan mengenai penyaluran barang dan jasa dari tangan produsen ke tangan komsumen

\footnotetext{
${ }^{25}$ Mursid, Manajemen Pemasaran, 26.
} 
4) Menurut asosiasi pemasaran amerika mendefinikan pemasaran adalah satu fungsi organisasi dan seperangkat proses untuk menciptakan, mengomunikasikan, dan menyerahkan nilai kepada pelanggan dan mengelola hubungan pelanggan dengan cara yang menguntunkan organisasi dan para pemilik sahamnya. ${ }^{26}$

b. Sifat dan dasar pemasaran

1) setiap perencana dan operasi harus berorientasi konsumen, setiap departemen dan karyawan harus difokuskan pada kontribusi untuk memenuhi kebutuhan konsumen

2) setiap aktivitas pemasaran dalam perusahaan harus dikoordinasikan

3) pesaran yang terkoordinir, berorientasi konsumen harus diutamakan untuk mencapai kinerja perusahaan.

c. Tujuan pemasaran

Tujuan pemasaran ada dua yaitu: ${ }^{27}$

1) Konsumen potensial megetahui secara detail produk yang kita hasilkan dan perusahaan dapat menyediakan semua permintaan mereka atas produk yang dihasilkan.

2) Perusahaan dapat menjelaskan secara detail semua kengiatan yang berhubungan dengan pemasaran.

Pengertian Strategi Pemasaran

Menurut bennett yang di kutip oleh Effendi M Guntur mendefinisikan strategi pemasaran merupakan pernyataan (baik secara implisit maupun eksplisit) mengenal bagaimana suatu merek atau lini produk mencapai tujuan. ${ }^{28}$

Menurut Tull dan Kahle yang di kutip oleh Effendi $M$ Guntur mendefinisikan strategi pemasaran sebagai alat fundamental yang direncanakan untuk mencapai tujuan perusahaan dengan mengembangkan keunggulan

${ }^{26}$ Guntur, transformasi manajemen pemasaran, 3.

${ }^{27}$ Guntur, transformasi manajemen pemasaran, 50

${ }^{28}$ Guntur, Transformasi Manajemen Pemasaran, 37 
bersaing yang berkesinambungan melalui pasar yang di masuki dan program pemasaran yang digunakan untuk melayani pasar sasaran tersebut. ${ }^{29}$

Menurut Gregorius Strategi pemasaran merupakan rencana yang menjabarkan espektasi perusahaan akan dampak dari berbagai aktivitas atau perogram pemasaran terhadap permintaan produk atau lini produk di pasar sasaran. ${ }^{30}$

Menurut corey yang di kutip oleh Effendi M Guntur, strategi pemasaran terdiri atas lima elemen yang saling berkait. Kelima eleme tersebut adalah: ${ }^{31}$

a. Pemilihan pasar, yaitu memilih pasar yang akan dilayani. Keputusan ini didasarkan pada faktor-faktor (jain, 1990):

1) Persepsi terhadap fungsi produk dan pengelompokan teknologi yang dapat diproteksi dan didominasi.

2) Keterbatasan sumber daya internal yang mendorong perlunya pemusatan (fokus) yang lebih sempit.

3) Pengalaman komulatif yang didasarkan pada trial-and-error di dalam menanngapi peluang tantangan

4) Kemampuan khusus yang berasal dari akses terhadap sumber daya langka atau pasar terproteksi.

b. Perencanaan produk, meliputi spesifik yang dijual, pembentukan lini produk, dan desain penawaran individu yang masing-masing lini produk itu sendiri menawarkan manfaat total yang dapat diperoleh pelanggan dengan melakukan pembelian.

c. Penetapan harga, yaitu menentukan harga yang dapat mencerminkan nilai kuantitatif dan produk kepada pelanggan.

d. Komunikasi pemasaran (promosi), yang meliputi periklanan, personal selling, promosi penjualan, direct marketing, dan public relations

${ }^{29}$ Guntur, Transformasi Manajemen Pemasaran, 37

${ }^{30}$ Chandra, Strategi dan Program Pemasaran, 93.

${ }^{31}$ Guntur, Transformai Manajemen Pemasaran, 37. 


\section{Bauran Pemasaran}

a. produk

Produk merupakan segala sesuatu yang dapat ditawarkan produsen untuk diperhatikan, diminta, dicari, dibeli, digunakan, atau dikonkumsi pasar sebagai pemenuhan kebutuhan atau keinginan pasar yang bersangkutan. ${ }^{32}$

1) Klasifikasi produk

Produk dapat diklasifikasikan kedalam dua kelompok utama, yaitu: ${ }^{33}$

a) Barang

Barang merupakan produk yang berwujud fisik, sehingga bisa dilihat, diraba/disentuh, dirasa, dipegang, dipindahkan, dan perlakuan fisik lainnya. Ditinjau dan aspek daya tahannya terdapat dua macam barang, yaitu:

b) Barang tidak tahan lama (nondurable goods)

Barang tidak tahan lama adalah barang berwujud yang biasanya habis dikonsumsi dalam satu tau beberapa kali pemakaian. Dengan kata lain, umur ekonomisnya dalam pemakaian normal kurang dari satu tahun.

c) Barang tahan lama

Barang tahan lama adalam merupakan barang berwujud yang biasanya bisa bertahan lama dengan banyak pemakaian (umur ekonomisnya untuk pemakaian normal adalah satu tahun atau lebih)

d) Jasa (services)

Jasa merupakan aktivitas, manfaat atau kepuasan yang ditawarkan untuk dijual.

2) Proses perencanaan strategi produk

Proses perencanaan strategi produk meliputi beberaapa langkah, yaitu: ${ }^{34}$

32 Guntur, transformasi manajemen pemasaran ,131

33 Guntur, transformasi manajemen pemasaran, 134-135

${ }^{34}$ Guntur, transformasi manajemen pemasaran , 145 
a) analisis situasi

Analisis situasi dilakukan terhadap lingkungan internal dan lingkungan eksternal

b) penentuan tujuan produk

Selain untuk memenuhi kebutuhan pelanggan, produk yang dihasilkan perusahaan dimaksudkan pula untuk memenuhi atau mencapai tujuan perusahaan

c) penentuan sasaran pasar

Perusahaan dapat berusaha melayani pasar secara keseluruhan ataupun melakukan segementasi.

b. Harga

Harga merupakan satuan moneter atau ukuran lainnya (termasuk barang dan jasa lainnya) yang ditukarkan agar memperolah hak kememilikan atau penggunaan barang atua jasa. 35

1) Tujuan penetapan harga

Pada dasarnya terdapat empat jenis tujuan penetapan harga, yaitu: ${ }^{36}$

a) tujuan berorientasi pada laba

Asumsi teori ekonomi klassik menyatakan bahwa setiap perusahaan selalu memilih harga yang dapat menghasilkan laba peling tinggi

b) tujuan berorientasi pada volume

Harga ditetapkan sedemikina rupa agar dapat mencapai target volume penjualan (dalam ton, kg, unit, m3, dan lain lain), nilai penjualan (Rp) atau pangsa pasar (absolut maupun relatif)

c) tujuan berorientasi pada citra

Citra (image) suatu perusahaan dapat dibentuk melalui strategi penetapan harga.

35 Guntur, transformasi manajemen pemasaran , 191

${ }^{36}$ Guntur, transformasi manajemen pemasaran, 195-197 
d) Tujuan stabilisasi harga

Dalam pasar yang konsumennya sangat sensitif terhadap harga, bila suatu perusahaan menurunkan harganya, maka para pesaingnya harus menurunkan pula harganya.

2) Faktor-faktor yang perlu dipertimbangkan dalam penetapan harga

a) Tujuan pemasaran perusahaan

Faktor utama yang menentukan dalam penetapan harga adalah tujuan pemasaran perusahaan

b) Strategi bauran pemasaran

Harga hanyalah salah satu komponen dari bauran pemasaran. Oleh karena itu, harga perlu dikoordinasikan dan saling mendukung dengan bauran pemasaran lainnya, yaitu produk, ditribusi, dan promosi.

c) Biaya

Biaya merupakan faktor yang menetukan harga minimal yang harus ditetapkan agar perusahaan tidak mengalami kerugian

d) Organisai

Manajemen perlu memutuskan siapa dalam organisasi yang harus menetapkan harga

e) Pesaing

Menurut porter (2006) ada lima kekuatan pokok yang berpengaruh dalam persaingan dalam suatu industri, yaitu persaingan dalam industri yang bersangkutan, produk subtitusi, pemasok, pelanggan, dan ancaman pendatang baru ${ }^{37}$

f) Tempat (place)

Tempat (place)fungsi distribusi dan logistik yang dilibatkan dalam rangka menyediakan produk dan jasa sebuah perusahaan. ${ }^{38}$

37 Guntur, transformasi manajemen pemasaran, 195-196

${ }^{38}$ Basma Hairani, "Strategi Pemasaran Produk Tabungan Wadi'ah Dan Mudharabah Dalam Meningkatkan Jumlah Nasabah Pada Bank Riau Kepri Syariah (Studi Kasus Pada Unit Layanan 
Lokasi dekat dengan jauh memperngaruhi biaya produksi. Adapun sungsi saluran distribusi: 39

1) Sebagai alat memperlancar keuangan perusahaan

2) Sebagai alat komunikasi

3) Sebagai alat bantu penjualan atau promosi

g) Promosi

Promosi adalah komunikasi yang persuasif, mengajak, mendesak, membujuk, meyakinkan. ${ }^{40}$

1) Tujuan promosi

Secara garis besar tujuan dapat dibagi menjadi dua: ${ }^{41}$

a) Tujuan jangka panjang (misalnya: membangung nama baik perusahaan, mendidik konsumen, dan menciptakan reputasi tinggi dari suatu produk)

b) Tujuan jangka pendek (misalnya menaikkan penjualan, mengumumkan lokasi agen dan mengumumkan perubahan/penyempurnaan produk)

2) Target promosi

a) Pemakai/calon pemakai

b) Si pembawa pengaruh

c) Penyalur

d) Bank

e) Masyarakat luas

f) Pemerintah ${ }^{42}$

3) cara promosi

Ada aneka macam melakukan promosi, dan kecendrungannya ialah cara yang dipakai semakin berkembang.

Syariah Cabang Bengkalis Dan Dumai)", Tesis, (Universitas Islam Negeri Sultan Syarif Kasim, Pekanbaru, 2012). 19

${ }^{39}$ Agustina Shinta, Manajemen Pemasaran , (Malang: UB Press.2011), 95

${ }^{40}$ Mursid, Manajemen Pemasaran, 95

${ }^{41}$ Mursid, Manajemen Pemasaran, 95

${ }^{42}$ Mursid, Manajemen Pemasaran, 95-96 
Secara garis besar kelompok cara promosi dapat dibagi menjadi sebagai berikut: 43

a) Periklanan (advertising)

Periklanan dipandang sebagai kengiatan penawaran kepada suatu kelompok masyarakat baik secara langsung lisan mauppun dengan penglihatan (berupa berita) tentang suatu produk, jasa dan ide.

Beberapa hal yang perlu diketahui mengenai kegiatan suatu periklanan, disini diantaranya ialah:

(1) Fungsi-fungsi periklanan yang di kemukakan

(a)Ada 5 (lima) fungsi periklanan

(b)Memberikan informasi

(c) Membujuk dan mempengaruhi

(d)Menciptakan kesan

(e)Memuaskan keinginan

(f) Sebagai alat komunikasi

(2) mengetahui aneka ragam media periklanan

Aneka media periklanan seperti majalah, persurat kabaran, radio, televisi, peragaan di tempat terbuka (sperti poster-poster, lambang/simbol, tulisan di angkasa), kiriman pos langsung, aneka tanda mata (geretan, kertas penghisap tinta, kalender), aneka kartu mobil atau bus, buku alamat dan surat edaran.

(3) Mengetahui cara penyajian periklanan

Untu penyajian suatu periklanan (advertising) maka perlu diperhatikan hal-hal sebagi berikut:
(a) Harus dapat menimbulkan perhatian
(b)Dapat menarik
(c) Dapat menimbulkan keinginan

${ }^{43}$ Mursid, Manajemen Pemasaran, 96-98 
4) Jenis iklan

Periklanan meliputi semua kengiatan yang terlibat dalam penyajian pesan yang non personal atau visual dan di biayai secar terbuka untuk suatu produk, jasa atau ide. ${ }^{44}$

a) Media cetak

Media cetak merupakan media yang bersifat statis, mengumumkan pesan dengan sejumlah kata, gambar, atau foto baik yang berwarna maupun hitam putih.

b) Media elektronik

Media elektronik yaitu media dengan teknologi elektronik dan hanya bisa digunakan bila ada jasa tranmisi siaran.

c) Media luar ruangan

Media luar ruangan merupakan media iklan yang dipasang ditempat terbuka seperti pinggir jalan, dipusat keramaian, tau tempattepat seperti di bus kota, gedung, pagar tebok, dan sebagainya. Jenis media luar meliputi: spanduk, baliho, poster, billboard, transit (panel bus), umbul-umbul dan lainnya.

d) Media lini bawah

Biasanya ada empat macam media yang digunakan dalam media lini bawah, yaitu pameran, kalender, point purchase, mechanizing scemes dan direct mail.

Menurut Gregorius Strategi pemasaran merupakan rencana yang menjabarkan espektasi perusahaan akan dampak dari berbagai aktivitas atau perogram pemasaran terhadap permintaan produk atau lini produk di pasar sasaran. ${ }^{45}$

Menurut corey yang di kutip oleh Effendi M Guntur, strategi pemasaran terdiri atas lima elemen yang saling berkait. Kelima eleme tersebut adalah: ${ }^{46}$

\footnotetext{
${ }^{44}$ Agustina, Manajemen Pemasaran , 131

45 Chandra, Strategi dan Program Pemasaran, 93.

${ }^{46}$ Guntur, Transformai Manajemen Pemasaran, 37.
} 
e. Pemilihan pasar, yaitu memilih pasar yang akan dilayani. Keputusan ini didasarkan pada faktor-faktor (jain, 1990):

5) Persepsi terhadap fungsi produk dan pengelompokan teknologi yang dapat diproteksi dan didominasi.

6) Keterbatasan sumber daya internal yang mendorong perlunya pemusatan (fokus) yang lebih sempit.

7) Pengalaman komulatif yang didasarkan pada trial-and-error di dalam menanngapi peluang tantangan

8) Kemampuan khusus yang berasal dari akses terhadap sumber daya langka atau pasar terproteksi.

f. Perencanaan produk, meliputi spesifik yang dijual, pembentukan lini produk, dan desain penawaran individu yang masing-masing lini produk itu sendiri menawarkan manfaat total yang dapat diperoleh pelanggan dengan melakukan pembelian.

g. Penetapan harga, yaitu menentukan harga yang dapat mencerminkan nilai kuantitatif dan produk kepada pelanggan.

h. Komunikasi pemasaran (promosi), yang meliputi periklanan, personal selling, promosi penjualan, direct marketing, dan public relations

\section{Strategi Pemasaran KBIH AI Mabrur}

Menurut Tull dan Kahle yang di kutip oleh Effendi M Guntur mendefinisikan strategi pemasaran sebagai alat fundamental yang direncanakan untuk mencapai tujuan perusahaan dengan mengembangkan keunggulan bersaing yang berkesinambungan melalui pasar yang di masuki dan program pemasaran yang digunakan untuk melayani pasar sasaran tersebut. ${ }^{47}$

Adapun strategi pemasaran yang dilakukan kelompok bimbingan ibadah haji (KBIH) Al Mabrur sebagai berikut:

${ }^{47}$ Guntur, transformasi manajemen pemasaran , 191 
a. Promosi

Adapun promosi yang digunakan oleh $\mathrm{KBIH}$ Al Mabrur seperti berikut:

Promosi dengan melakukan silaturrahim yaitu petugas bagian $\mathrm{KBIH} \mathrm{Al}$ Mabrur mendatangi langsung kepada calon jamaaah haji, dan melakukan silaturrahim ke alumni jamaah haji utnuk melakukan promosi secara langsung kepada jamaah.

Menyebarkan brosur suatu bentuk promosi yang dilakukan oleh KBIH AI Mabrur, brosur disebarkan kapada calon jamaah haji, kepada mantan jamaah. Dan berdampak pada kepercayaan oleh jamaah hajji yang belum menunaikan ibadah haji.

Strategi pemasaran menggunakan kalender suatu strategi yang dilakukan oleh pengurus $\mathrm{KBIH}$ Al Mabrur mulai tahun 2018. Promosi menggunakan kalender memberikan informasi yang cukup lengkap, kalender diberikan kepada jamaah haji mulai 2015 sampai 2018.

Apadun promosi menggunakan benner yang dilakukan oleh $\mathrm{KBIH} \mathrm{Al}$ Mabrur dengan memberikan benner kepada calon jamaah haji yang menunaikan ibdah haji setiap tahunnya. Dengan memberikan benner kepada kepada jamaah haji cukup efekti untuk melakukan promosi KBIH Al Mabrur.

Strategi promosi dengan menggunakan mantan jamaah haji yaitu jamaah yang ikut KBIH Al Mabrur ketika sudah menunaikan ibadah haji akan bercerita kepada orang lain, kalau mengiktuti bimbingan KBIH Al Mabrur atau promosi dari mulut ke mulut (word of mouth).

Dalam strategi pemasaran memberikan pelayanan prima merupakan bentuk promosi yang digunakan oleh $\mathrm{KBIH}$ Al Mabrur. Dengan meberikan pelayanan prima kepada jamaah haji secara tidak langsung jamaah haji KBIH Al Mabrur akan bercerita kepada orang laing.

Produk KBIH Al Mabrur ada dua, yaitu haji dan umroh. Ada haji reguler ada haji plus, untuk peketan umroh ada 3 macam, 9 hari, 13 hari, 16 hari.

Adapun harga yang ditetapkan oleh KBIH Al Mabrur sebesar 2.250.000 untuk bimbingan ibadah haji. sedangkan biaya umroh paket 9 hari 25.000.000, Volume 4, Nomor 2, Agustus 2018| 218 
13 hari 27.0000.000, 16 hari 30.000.000. untuk biaya haji plus setoran awal 70.000.000 dengan menetapkan harga untuk bisa bersaing dengan $\mathrm{KBIH}$ yang lain.

Tempat KBIH Al Mabrur cukup strategis karena berada di tengahtengah kota, berada di jalan Juanda No 10 Kelurahan Rogotrunan Kecamatan Lumajang Kabupaten Lumajang Provinsi Jawa Timur.

Adapun Strategi pemasaran yang dilakukan oleh KBIH Al Mabrur dapat dikaji dengan teoristrategi marketing mix. Adapun staretgi marketing mix ada empat, yaitu:

a. Promosi

Promosi adalah komunikasi yang persuasif, mengajak, mendesak, membujuk dan meyakinkan. ${ }^{48}$

Dalam strategi pemasaran dengan melakukan silaturrahim sama dengan Al-Faqih Abu Lais Samarqandi dalam buku habibillah. Bahwa silatrrahim menpunyai banya manfaat yaitu mendapatkan ridha dari Allah swt.,membahagiakan orang yang kita kunjungi, menyenangkan malaikat, karena malaikat juga sangat senang ber silaturrahim, disenangi oleh manusia, menambah banyak rezeki dan berkah, dan lain-lain. Memupuk rasa cinta kasih terhadap sesama, meningkatkan rasa kebersamaan rasa kekeluargaan, mempererat dan memperkuat tali persaudaraan dan persahabatan, menambah pahala setelah kematiannya, karena kebaikannya (dalam hal ini, suka bersilaturrahim) akan selalu dikenang sehingga membuat orang lain selalu mendoakannya. ${ }^{49}$

Ada aneka macam melakukan promosi, dan kecendrungannya ialah cara yang dipakai semakin berkembang. Secara garis besar kelompok cara promosi sebagai berikut:

${ }^{48}$ Mursid, Manajemen Pemasaran, 95

${ }^{49}$ Rachmat Syafi'i, al-Hadis: Aqidah, Akhlak, Sosial dan Hukum (Bandung:.CV Pustaka Setia2000,) 209. 
1) Penjualan personal

Penjualan personal adalah seni kuno, meskipun demikian, wiraniaga efektif saat ini mempunyai lebih dari sekedar isting.

Ada enam langkah mencari calon pelanggan dan mengkualifikasikannya, yaitu: ${ }^{50}$

a) Prapendektan

Wiraniaga harus menetapkan tujuan kunjungan, mengkualiafikasikan calon pelanggan, mengumpulkan informasi, melakukan penjualan segera.

b) Presentasi dan Demontrasi

Wiraniaga menyampaikan produk kepada pembeli, menggunaka pendekantan fitur, keunggulan, manfaat, dan nilai.

c) Mengatasi Keberatan

Untuk menangani keberatan ini, wiraniaga mempertahankan pendekatan positif, meminta pembeli mengklarifikasi keberatan, mengajukan pertanyaan dengan cara di mana pembeli keberatan sendiri, menyangkal keakuratan hal yang menjadi keberatan tersebut atau mengubah menjadi alasan utnuk membeli.

d) Penutupan

Wiraniaga dapat menanyakan pesanan, merekapitulasi poin-poin yang telah disepakati, menawarkan untuk membantu menulis pesanan.

e) Tindak lanjut dan pemiliharaan

Tindaj lanjut dan pemiliharaaan diperlukan untuk memastikan kepuasan pelanggan dan terulangnya kerja sama.

50 Philip Khotler dan Kevin Lane Keller, Manajemen Pemasaran, (Jakarta: PT Glora Aksara Pratama. 2009) 272 
f) Pemasaran hubungan

Wiraniaga yang bekerja sama dengan pelanggan kunci harus melakukan lebih dari sekedar menelepon ketika mereka menganggap pelanggan sudah siap untuk melakukan pemesanan.

2) Periklanan

Adapun media periklanan seperti berikut: ${ }^{11}$

e) Media cetak

Media cetak merupakan media yang bersifat statis, mengumumkan pesan dengan sejumlah kata, gambar, atau foto baik yang berwarna maupun hitam putih.

f) Media elektronik

Media elektronik yaitu media dengan teknologi elektronik dan hanya bisa digunakan bila ada jasa tranmisi siaran.

g) Media luar ruangan

Media luar ruangan merupakan media iklan yang dipasang ditempat terbuka seperti pinggir jalan, dipusat keramaian, tau tempattepat seperti di bus kota, gedung, pagar tebok, dan sebagainya. Jenis media luar meliputi: spanduk, baliho, poster, billboard, transit (panel bus), umbul-umbul dan lainnya.

h) Media lini bawah

Biasanya ada empat macam media yang digunakan dalam media lini bawah, yaitu pameran, kalender, point purchase, mechanizing scemes dan direct mail.

3) Berita dari mulut ke mulut

Ada dua macam pemasaran berita dari mulut ke mulut, yaitu: $5^{2}$

a) Pemasaran buzz

Pemasaran buzz (gosip atau perbincangan) menghasilkan ketertarikan, menciptakan publisitas, dan mengekpresikan informasi

${ }^{51}$ Agustina Shinta, Manajemen Pemasaran , 131

52 Philip Khotler dan Kevin Lane Keller, Manajemen Pemasaran. 254 
relevan baru berhubungan deng merek melalui sarana yang tak terduga atau bahkan mengejutkan.

b) Pemasaran viral

Pemasaran viral (menular seperti virus) adalah bentu lain berita dari mulut ke mulut yang mendorong konsumen menceritakan produk dan jasa yang dikembangkan peruhaan atau informasi audio, vidio, dan tertulis kepada orang laing secar online.

4) Menciptakan pengalaman

Pemasaran pengalaman yang tidak hanya mengkomunikasikan fitur dan manfaat, tetapi juga menghubungkan produk atau jasa dengan pengalaman unik dan menarik. Sebagian besar juga merasa bahwa pemasaran pengalaman memberikan merekan lebih banyak informasi dibandingkan bentuk komunikasi lainnya dan membuat mereka lebih ingin memberitahu orang lain untuk berpartisipasi dalam acara tersebut serta menerima pemasaran lain bagi merek tersebut. ${ }^{53}$

b. Harga

Harga adalah nilai yang dinyatakan dalam bentuk uang. Pada dasarnya terdapat empat jenis tujuan penetapan harga, yaitu: ${ }^{54}$

1) tujuan berorientasi pada laba

Asumsi teori ekonomi klassik menyatakan bahwa setiap perusahaan selalu memilih harga yang dapat menghasilkan laba peling tinggi

2) tujuan berorientasi pada volume

Harga ditetapkan sedemikina rupa agar dapat mencapai target volume penjualan (dalam ton, $\mathrm{kg}$, unit, m3, dan lain lain), nilai penjualan (Rp) atau pangsa pasar (absolut maupun relatif)

3) tujuan berorientasi pada citra

Citra (image) suatu perusahaan dapat dibentuk melalui strategi penetapan harga.

53 Philip Khotler dan Kevin Lane Keller, Manajemen Pemasaran. 229

${ }^{54}$ Guntur, transformasi manajemen pemasaran , 191 
4) Tujuan stabilisasi harga

Dalam pasar yang konsumennya sangat sensitif terhadap harga, bila suatu perusahaan menurunkan harganya, maka para pesaingnya harus menurunkan pula harganya.

c. Produk

Produk merupakan segala sesuatu yang dapat ditawarkan produsen untuk diperhatikan, diminta, dicari, dibeli, digunakan, atau dikonkumsi pasar sebagai pemenuhan kebutuhan atau keinginan pasar yang bersangkutan.

Proses perencanaan strategi produk meliputi beberaapa langkah, yaitu: 55

1) analisis situasi

Analisis situasi dilakukan terhadap lingkungan internal dan lingkungan eksternal

2) penentuan tujuan produk

Selain untuk memenuhi kebutuhan pelanggan, produk yang dihasilkan perusahaan dimaksudkan pula untuk memenuhi atau mencapai tujuan perusahaan

3) penentuan sasaran pasar

Perusahaan dapat berusaha melayani pasar secara keseluruhan ataupun melakukan segementasi.

d. Lokasi atau saluran distribusi

Lokasi dekat dengan jauh memperngaruhi biaya produksi. Adapun sungsi saluran distribusi: ${ }^{56}$

4) Sebagai alat memperlancar keuangan perusahaan

5) Sebagai alat komunikasi

6) Sebagai alat bantu penjualan atau promosi

${ }^{55}$ Guntur, transformasi manajemen pemasaran , 145

${ }^{56}$ Agustina Shinta, Manajemen Pemasaran ,95 


\section{Faktor Pendukung Strategi Pemasaran KBIH Al Mabrur}

a. Adanya Loyalitas Jamaah Haji

Yang mejadi faktor pendukung strategi pemasaran $\mathrm{KBIH} A \mathrm{Al}$ Mabrur yaitu adanya loyalitas jamaah haji. Dengan loyalitas jamaah haji setiap tahunnya jamaah haji cukup banyak. Karena biasanya jamaah haji ikut KBIH Al Mabrur ketika anaknya, saudaranya diikutkan ke KBIH Al Mabrur juga.

Adanya Loyalitas Jamaah Haji yang menjadi faktor pendukung startegi pemasaran $\mathrm{KBIH}$ Al Mabrur ada kesamaan dengan teori yang dijelaskan Dick dan Basu dalam bukunya Muhammad Adam.

Dick dan Basu menjelaskan telah membagi membagi loyalitas pelanggan menjadi empat kategori, yaitu: ${ }^{57}$

1) Captive

Pelanggan yang captive akan melanjutkan untuk mempolakan merek atau jasa yang mereka beli kerena mereka tidak punya pilihan lain.

2) Convennience-skecer

Pelanggan loyal bukan pada merek tetapi pada kenyamanan yang mereka inginkan ketika membeli suatu merek.

3) Contented

Pelanggan yang loyalitas ini mempunyai sikap yang positif terhadap merek tetapi inersia dalam prilaku mereka.

4) Committed

Pelanggan yang komit memiliki sikap dan prilaku ynag positif, mereka sangat terlibat dengan merek yang mereka beli dan bersedia menceritkan hal-hal yang positif tentang merek tersebut.

b. Pemberian pelayanan yang baik

Pemeberian pelayanan yang baik dilakukan oleh KBIH Al Mabrur mulai dari bimbingan manasik di Indonesia, di Makkah, di Madinah sampai dengan pulang ke indonesia.

57 Muhammad Adam, manajemen pemasaran jasa. (Bandung: CV Alfabeta. 2015) 63 Volume 4, Nomor 2, Agustus 2018| 224 
Adapun pelayanan yang baik dilakukan oleh KBIH Al Mabrur ada kesamaan dengan teori yang dijelaskan Sutopo dan Adi Suryanto tentang pemberian pelayanan yang baik.

Menurut sutopo dan adi suryanto tentang karakteristik tentang pelayanan agar menjadi dasar sebagaiman memberikan pelayanan yang terbaik, yaitu: ${ }^{58}$

1) Pelayanan bersifat tidak dapat diraba, pelayanan sangat berlawanan sifatnya dengan barang jadi.

2) Pelayanan itu kenyataannya terdiri dari tindakan nyata dan merupakan pengaruh yang sifatnya adalah tindakan sosial.

3) Produksi dan konsumsi dari pelayanan tidak dapat dipisahkan secara nyata, karena pada umumnya kejadian bersamaan den terjadi di tempat yang sama.

c. Harga yang Terjangkau

Harga yang ditetapkan oleh KBIH Al Mabrur menyesuaikan dengan produk yang diberikan, dengan harga 2.250 .000 kbih al mabrur berada di antara KBIH yang lain. Artinya ada yang memebrikan harga bimbingan diatasnya KBIH Al Mabrur juga ada yang dibawahnya KBIH Al Mabrur.

Adapun harga yang ditetapkan oleh $\mathrm{KBIH}$ Al Mabrur ada kesamaan dengan teori yang dijelaskan oleh danang sunyoto dalam bukunya.

Adapun tujuan penetapan harga menurut danang sunyoto sebagai berikut: 59

1) Penetapan harga untuk mencapai suatu target

2) Stabilisasi harga dan margin

3) Penetapan harga untuk mencapai target market share

4) Penetpan harga untuk mengtasi atau mencengah persaingan

5) Penetapan harga untuk memaksimumkan laba

${ }^{58}$ Sutopo dan Adi Suryanto, pelayanan prima. (Jakarta: Lembaga Adiministrasi Negara. 2001) 8 ${ }^{59}$ Danang Sunyoto, strategi pemasaran. (yogyakarta:pt buku seru.2015) 128 
d. Adanya Ikatan Alumni Jamaah Haji

Sementara faktor pendukung strategi pemasan KBIH Al Mabrur yaitu adanya ikatan alumni jamaah haji, setiap tahunnya mengadakan reuni dan biasanya ketua KBIH Al Mabrur yang mendatangi acara reuni untuk sambuatan dan menjaga hubungan dengan dengan para alumni jamaah haji.

Faktor pendukung strategi pemasaran KBIH Al Mabrur ketika ketua menhadadiri acara reuni untuk menjaga hubungan tehadap jamaah, ada kesamaah dengan teori pemasaran dengan hubungan masyarakat yang dijelaskan oleh Danang Sunyoto.

Danang sunyoto menjelaskan pengertian hubungan masyarakat adalah merupakan pemasaran penting lainnya dimana perusahaan tidak hanya harus berhubungan dengan pelanggan, pemasok dan penyalur, tetapi juga harus berhubungan dengan kumpulan kepentinagn publik yang besar. Program hubungan masyarakat antara lain publiskasi, acara-acara penting, hubungan dengan investor, pameran dan mensponsori acara. ${ }^{60}$

e. Petugas KBIH Al Mabrur yang Merata di Kabupaten Lumajang

Adapun yang menjadi faktor pendukung stretegi pemasan $\mathrm{KBIH}$ Al Mabrur petugas yang merata di Kabupaten Lumajang. Petugas yang merata di kabupaten lumajang sangat efektif untuk menjangkau para calon jamaah yang baru akan direkrut.

Adanya petugas yang merata ada kesamaan dengan teori strategi wiraniaga yang dijelaskan oleh Mahmud Machfoedz. Mahmud Machfoedz menjelaskan wiraniaga bekerja mengjangkau konsumen dengan beberapa cara sebagai berikut: ${ }^{61}$

1) Wiraniaga kepada konsumen

Wiraniaga membicarakab pokok perusahaan dengn konsumen atau propek secara tatap muka atau melalui telepon.

60 Sunyoto, strategi pemasaran. 159

${ }^{61}$ Machfoedz,Pengantar Pemasaran Modern, 117 
2) Wiraniaga kepada kelompok konsumen

Wiraniaga memberi informasi sebanyak munkin kepada anggota kelompok kosumen.

3) Tim penjualan kepada kelompok konsumen

Tim penjualan perusahaan melayani anggota kelompok konsumen dengan cara yang akrab.

4) Konfrensi penjualan

Wiraniaga membicarakan permasalahan atau kesempatan penjualan dengan pihak pengelola sumber daya perusahaan.

5) Seminar penjualan

Tim perusahaan menyelenggarakan seminar pendidikan untuk membina konsumen

\section{Faktor penghambat strategi pemasaran KBIH Al Mabrur}

Kelompok bimbingan ibadah haji (KBIH) Al Mabrur dalam pelaksanaan startegi pemasaran selain ada faktor pendukung, juga ada faktor penhambat startegi pemasaran KBIH Al Mabrur. Diantaranya adalah sebagai berikut:

a. Adanya Pesaing

Yang menjadi salah satu faktor penghambat strategi pemasaran $\mathrm{KBIH}$ Al Mabrur yaitu adanya pesaing. Di kabupaten lumajang ada $6 \mathrm{KBIH}$ yang melayani bimbingan masnik haji, adapun yang dilakukan oleh $\mathrm{KBIH} \mathrm{Al}$ Mabrur dalam memutuskan kebijakan, salah satunya dengan melihat pesaing dari segi harga.

Yang menjadi faktor penghambat strategi pemasaran $\mathrm{KBIH} A \mathrm{Al}$ Mabrur adanya pesaing yang dilakukan oleh KBIH Al Mabrur ada kesamaan dengan teori yang dijelaskan oleh Michael E Porter.

Michael E Porter menjelaskan hadirnya pesaing yang baik dapat membawa berbagai manfaat startegis yang bisa digolongkan ke dalam empat kategori: meningkatkan keunggulan bersaing, memperbaiki strtuktur 
organisasi yang ada, membantu perkembangan pasar, dan menghalagi pesaing yang baru. ${ }^{62}$

b. Kurangnya Sumber Daya Manusia (SDM)

Adapun yang menjadi faktor penghambat strategi pemasaran KBIH Al Mabrur yaitu kurangnya sumber daya manusia (SDM) yang ada di kantor setiap harinya. Karena ketika ada pengumpulan berkas yang banyak akan kewalahan untuk mengejakannya.

Kurangnya sumber saya manusia akan berdampak terhadapat produktivitas kinerja karyawan. Ada kesamaan dengan teori yang dijelaskan oleh M Yani.

M Yani menjelaskan suatu perusahaan melakukan penilaian didasarkan pada dua alasan pokok, yaitu:63

1) Manajer memerlukan evaluasi yang objektif terhadap kinerja karyawan pada masa lalu yang digunakan untuk membuat keputusan di bidang SDM di masa yangakan datang

2) Manajer memerlukan alat yang memungkinkan untuk membantu karyawan memperbaiki kinerja, merencanakan pekerjaan, mengembangkan kemampuan dan keterampilan untuk perkembangan karir dan memperkuat hubungan antar manajer yang bersangkutan dengan kartyawan.

c. Tidak Mempunyai Blog atau Wabsite

Faktor penghambat dalam strategi pemasaran $\mathrm{KBIH}$ Al Mabrur karena tidak mempunyai blog wabsite sehingga dalam melakukan promosi di dalam media online kurang maksimal.

Dalam teori strategi marketi mix promosi dilakukan dengan menggunakan media internet pada sekarang sangat dibutuhkan untuk menjangkau konsumen yang jauh.

Nimbah F Hartimbul Ginting menjelaskan bahwa ada tiga media dalam mempromosikan suatu produk:

${ }^{62}$ Michel E porter, keunggulan bersaing, (Jakarta: PT Glora Aksara Pratama. 1993) 191

${ }^{63}$ M Yani, manajemen sumeber daya manusia. (Jakarta: Mitra Wacana Media. 2012) 119 Volume 4, Nomor 2, Agustus 2018| 228 
1) Media utama yang bisa dipilih: Koran, TV, Internet, Pos, Radio, Majalah, Oudoor

2) Media yang lebih khusus pada setiap tipe, TV dan stasiun, acara, majalah, koran

3) Memilih waktu yang tepat pengiklan bisa mengikuti jalannya musim penjulan, memilih waktu-waktu terbaik.

\section{KSIMPULAN}

Berdasarkan hasil analisa dan penelitian, maka dapat diambil kesimpulan bahwa:

1. Strategi pemasaran yang dilakukan $\mathrm{KBIH}$ Al Mabrur adalah menggunakan bauran pemasaran atau marketing mix dengan tahapan, pertama melakukan promosi, kedua menyediakan produk yang di inginkan pelanggan, ketiga harga yang terjangkau, keempat lokasi yang strategis.

2. Faktor pendukung strategi pemasaran KBIH Al Mabrur adalah adanya loyalitas jamaah haji, pemberian pelayanan yang baik, harga yang terjangkau, adanya ikatan almuni jamaah haji, petugas KBIH Al Mabrur yang cukup merata di Kabupaten Lumajang.

3. Faktor penghambat strategi pemasaran KBIH Al Mabrur adalah adanya pesaing, kurangnya sumber daya manusia (SDM), tidak mempunyai blog atau wabsite

\section{REFERENSI}

Adam,Muhammad. Manajemen Pemasaran Jasa. Bandung: CV Alfabeta, 2015.

Arikunto, Suharmisi. Prosedur Penelitian Suatu Pendekan Peraktik, Jakarta: PT Rineka Cipta, 2006.

Bashri, Muh. Mu'inudinillah \& Elly Damaiwati. Kuketuk Pintu Rumah-Mu Ya Allah, Surakarta:Indiva Pustaka, 2009.

Chandra, Gregorius. Strategi dan Program Pemasaran, Yogyakarta: Andi, 2002.

Guntur, Effendi M. Transformasi Manajemen Pemasaran. Jakarta: CV Sagung Seto, 2010.

http://jatim.kemenag.go.id/file/file/haji/isaq1426576477.pdf. diakses 1 februari 2018 
Khotler, Philip dan Kevin Lane Keller. Manajemen Pemasaran, Jakarta: PT Glora Aksara Pratama, 2009.

Kotler dan Amrstrong. Perinsip-Perinsip Pemasaran, Jakarta: Erlangga, 2001

Machfoedz, Mahmud. Pengantar Pemasaran Modern Yokyakarta: Akademi Manajemen Perusahaan YKPN, 2005.

Devi Noviyanti, "Pentingnya Implementasi Strategi Pemasaran Bagi Travel Haji dan Umroh di Banjarmasin” jurnal ilmu dakwah juli-desember 2015

Mursid, M.. Manajemen Pemasaran. Jakarta: PT Bumi Aksara, 2003.

Imam Syaukani, Manajemen Pelayanan Haji Di Indonesia (Departemen Agama RI Badan Litbang dan Diklat Puslitbang Kehidupan Keagamaan, 2009

Moleong, Lexy J. Metodologi Penelitian Kualitatif. Bandung: Remaja Rosydakarya, 2002.

Noviyanti, Devi, “Pentingnya Implementasi Strategi Pemasaran Bagi Travel Haji dan Umroh di Banjarmasin" jurnal ilmu dakwah juli-desember 2015.

Syafe'i, Rahmat. Al-Hadis: Akidah, Akhlak, Sosial dan Hukum. Bandung: Pustaka Setia, 2000.

Rosadi, Mochammad Ali. Strategi Pemasaran Kelompok Bimbingan Ibadah Haji (Studi Komparasi KBIH Bryan Makkah Dan KBIH Takhobbar Surabaya),Skripsi,Surabya: agama islam negeri sunan ampel,2013.

Shinta, Agustina. Manajemen Pemasaran. Malang: UB Press, 2011.

Sugiyono. Metode Penelitian Kuatitatif Kualitatif dan R\&D. Bandung: alfabeta, 2010.

Sutopo dan Adi Suryanto. Pelayanan Prima. Jakarta: Lembaga Adiministrasi Negara, 2001

Sunyoto, Danang. Strategi Pemasaran. Yogyakarta:PT Buku Seru, 2015.

Syaukani, Imam..Manajemen Pelayanan Haji Di Indonesia. Departemen Agama RI Badan Litbang dan Diklat Puslitbang Kehidupan Keagamaan, 2009

Widyarini, “Manajemen Kelompok Bimbingan Ibadah Haji (KBIH)", Jurnal Ekonomi dan Bisnis Islam 2 juni 2013.

Yani, M. ManajemenSumber Daya Manusia. Jakarta: Mitra Wacana Media, 2012. 